10.2478/aucft-2020-0018

\title{
NUTRITIONAL, ANTINUTRITIONAL AND PHENOLIC PROPERTIES OF LIMA BEAN (PHASEOLUS LUNATUS) ACCESSIONS: UNDERUTILIZED LEGUME IN ETHIOPIA
}

- Research paper -

\author{
Habtamu Fekadu GEMEDE ${ }^{1}$, Etana BIRHANU
}

Department of Food Technology and Process Engineering, Wollega University, P.O. Box 395, emails: fekadu_habtamu@yahoo.com, etanabirhanu@yahoo.com, Nekemte, Ethiopia.

\begin{abstract}
The study was aimed to evaluate nutritional compositions, anti- nutritional factors and antioxidant properties of lima bean accessions grown in East Shoa Zone, Ethiopia. The lima bean accessions were studied and compared for their nutritional composition, anti-nutritional factors and antioxidant properties. The result showed that lima bean accessions were good source of vital nutrients when compared to the commonly consumed legumes in Ethiopia. Particularly, lima bean accessions "LB8510" rich in crude protein whereas accession "LB85CH2" rich in crude fiber, total ash and iron and can be implemented for breeding, new product development and used as alternative source of nutrient rich to mitigate malnutrition prevalent in Ethiopia. Therefore, increasing its consumption, cultivation and promotion should be encouraged.
\end{abstract}

Keywords: Lima bean, Accession, Nutritional, Anti-nutritional and Antioxidants

\section{INTRODUCTION}

Protein energy deficiency is one of the major problems in Ethiopia (Yagoub et al 2008). In Africa and in developing countries, animal proteins are grossly inadequate and relatively expensive (Adebowale et al., 2005). To improve protein deficiency, the diet should be supplemented with protein rich food. Among the plant species, grain legumes are considered as the major source of dietary proteins (Esenwah and Ikenebomeh, 2008). In this regard, plant food commodities like legumes are the best source of protein (Amarteifio et al., 2005).

In many countries including Ethiopia, due to due to their rich protein composition and cheap costs, legumes are considered best source of "poor man's meat" (Sathya and Siddhuraju, 2015). Legumes play very important role due to the nutritional quality (Pedrosa et al., 2012). According to Genovese and Lajolo, (2001), the protein contents of legumes are ranged from $17-40 \%$, but cereals contain about $7-13 \%$. Legume proteins complement cereal proteins to provide source of dietary protein of vegetal origin for human beings.

Received: 05.10.2020.

Accepted in revised form: 20.11.2020
This is because cereal proteins which are deficient in lysine and rich in methionine and cystine complement legume proteins which are rich in lysine and poor in methionine and cystine (Iqbal, 2006; Michaels, 2004).

Lima bean has many nutritional and health contribution (Tharanathan and Mahadevamma, 2003). Lima bean seeds are good sources of nutrients such as proteins, carbohydrates, crude fiber and minerals like calcium, phosphorus, iron (Kathirvel and Kumudha, 2011). The antinutritional factors found in lima bean seeds include phytic acids, oxalate and tannins (Ezeagu and Ibegbu, 2010). Lima bean could easily be utilized in combination with cereals and roots and tubers crops (Apata and Ologhobo, 1994). So, it is essential to introduce new foods that are underutilized, easy for people with a low income to purchase and being suitable to the environment to be cultivated based on evidential information. However, lima bean is an underutilized and orphan crop. Therefore, it is very paramount to introduce underutilized crops like lima bean. and there is no published data available for its proximate composition, mineral composition, anti-nutritional factors and anti-oxidant properties of lima bean accession particularly grown in east shoa zone, Ethiopia. We propose to fill this gap in this research.

${ }^{1}$ Corresponding author. E-Mail address: fekadu_habtamu@yahoo.com 


\section{MATERIALS AND METHODS}

\section{Sample collection and preparation}

Seeds of four lima beans accessions namely: LB45CH, LB45 PL, LB8510 and LB85CH2 were collected from Melkesa Research Institute experimental site and coded, packed into airtight polyethylene plastic bags, kept in an ice box (to prevent moisture loss), and transported to Ethiopian health and nutrition research institute.

The collected lima bean seeds accessions were cleaned and sorted to avoid the foreign material. The raw lima bean accessions were milled into fine powder using electric grinder (NIMA8300Burman, Germany) until to pass through $0.425 \mathrm{~mm}$ sieve mesh size. The powder was then packed and stored until used for further analysis.

\section{Proximate compositions analysis}

The proximate analysis (protein, fat, ash, fiber and moisture) were conducted according to AOAC, 2016. Gross energy was conducted according to Guyot et al., (2007). Analytical grade chemicals were used.

\section{Mineral composition Analysis}

The methods of AOAC (2000) were used to destroy organic matrix by ashing in muffle furnace. Minerals (calcium, irons, zinc and magnesium) concentrations were analyzed by atomic absorption spectrophotometer (AAS). Whereas, sodium and potassium were conducted by using the standard flame emission photometer (Adeyeye and Adesina, 2018).

\section{Anti-Nutritional Factors Analysis}

The condensed tannin content of the sample was determined according to the modified Vanillin $\mathrm{HCl}$ methanol method as described by Burns (1971), Morris and Ellis, (1989); Abera, (2014). The phytic acid content was determined by the method described by Latta and Eskin (1980). The permanganate titration method described by Ojinnaka et al., (2013) and Omoruyi et al., (2007) was used.

\section{Phenols determination}

The total phenol composition was determined by calorimetric method described by Singleton and Rossi (1965). The total flavonoid was evaluated by the method of Arvouet-Grand et al. (1994). Antioxidant activity was evaluated according to the procedure described by Bursal et al. (2011).

\section{Statistical Analysis}

Two replicates and CRD design was used. All analyses were conducted using SPSS (SPSS Institute Inc., Cary, NC) software. Analysis of variance is used to evaluate data and Duncan's multiple range tests were used to separate mean \pm SE (standard error). Significant difference was considered at P-value of 0.05 or less.

\section{RESULTS AND DISCUSSIONS}

\section{Proximate compositions}

Table 4.1shows the moisture contents of lima bean accessions. The moisture contents the accessions varied from9.32\%in "LB85CH2" to $9.84 \%$ in "LB8510" on dry weight basis. Accession "LB8510" had high moisture content $(9.84 \%)$ and was followed by "LB45pL" (9.62\%) and "LB45CH" $(9.52 \%)$ in that order. On other hand, accession "LB85CH2" had significantly $(P<0.05)$ lowest $(9.32 \%)$ moisture contents of all accessions. The mean moisture composition of the accession sample was $9.58 \%$, which was comparable with the moisture content of $9.60 \%$ for some underutilized legume as reported by Ogunlade et al. (2014) and Lentils (Lens culinaris) 9.40\%, Vetch (Lathyrus sativus) $9.30 \%$ and Lupine (lupins spp.) $9.30 \%$ as reported by the Ethiopian Health and Nutrition Research Center (EHNRI) (1997). The mean moisture content was lower than the mean of $10.04 \%$ for lablab beans reported by
Soetan and Fafunso (2010) and Arkroyed and Doughty, (1994).

The crude protein content of the studied accessions was shown in Table 4.1. The crude protein contents of lima bean accessions were ranged from $23.98-24.76 \%$ on dry weight basis. The crude protein of accession "LB8510" had significantly higher $(24.76 \%)$ and was followed by "LB45PL" $(24.33 \%)$ and "LB85CH" $(24.06 \%)$ in that order. Accession "LB45CH" had significantly $(\mathrm{p}<0.05)$ lower (23.98) in crude protein contents than other accessions. The accessions contain a mean of $24.28 \%$ crude protein. The mean protein content was agreed with the value $24.15 \%$ for Rongai brown legumes reported by Soetan and Fafunso (2010) and 24.6\% for lima bean reported by Baddi et al. (2016). But it was lower than the values reported by Fasoyiro et al. (2006) for bean (30 to $40 \%$ ), soybean (33 to $41 \%$ ) and pigeon pea (28 to 29\%). The commonly consumed legumes in Ethiopia and their protein content are: raw Chickpeas (Cicer arietinum) 19.40g/100g; Lentils (Lens culinaris) 21.80g/100g; Peas (Pisum 
sativum) 20.10g/100g; Vetch (Lathyrus sativus) $22.10 \mathrm{~g} / 100 \mathrm{~g}$; Fenugreek (Trigonlla foenum graecum) 19.30g/100g; Broad beans (Vicia faba) $23.10 \mathrm{~g} / 100 \mathrm{~g}$, all with lower protein contents than lima accessions by EHNRI (1997).

Crude fat content of lima bean accessions is shown in Table 1. The crude fat content of the accessions varied from $2.78 \%$ in" $\mathrm{LB} 85 \mathrm{CH}$ " to $2.94 \%$ in "LB45PL" on dry weight basis. Accession "LB45PL" had high crude fat content $(2.94 \%)$ and was followed by "LB8510" (2.87\%), "LB45CH" $(2.86 \%)$ and "LB85CH2" $(2.78 \%)$ in that order. They were not significantly difference $(p>0.05)$ between all lima bean accessions. The mean fat content of the accessions under study was $2.26 \%$. The result was comparable with $2.35 \%$ for lima bean varieties reported by Seidu et al. (2018). The mean fat content of the present finding was higher than the value reported by Yellavila et al. (2015) for lima bean $(0.59$ to1.14 \%) and lower than the value reported by Soetan and Fafunso (2010) for 9.64\% for three varieties of Lablab Beans (9.64\%). The commonly consumed legumes in Ethiopia such as Chickpeas (Cicer arietinum) $5.80 \mathrm{~g} / 100 \mathrm{~g}$, Lupine (lupins spp.) $8.30 \mathrm{~g} / 100 \mathrm{~g}$ and Fenugreek (Trigonlla foenum graecum) $7.20 \mathrm{~g} / 100 \mathrm{~g}$ had higher fat contents than the lima bean accessions under (EHNRI 1997). Excess consumption of fat has many health complicated (Aruah et al., 2011), in this regard, the consumption of lima bean accessions should be encouraged.

The crude fiber of lima bean accessions ranged from $5.59 \%$ to $6.09 \%$ in "LB45PL" and "LB85CH2" accessions, respectively. Accession "LB85CH2" had higher fiber content. The mean crude fiber content of Lima bean accessions was $5.92 \%$, which was comparable with the mean crude fiber contents $5.63 \%$ for underutilized seed beans reported by Ogunlade et al. (2014). The result was relatively similar with $4.81 \%$ for lima bean accession as reported by Yellavila et al. (2015). The mean fiber content of the accessions was $5.92 \%$, which was higher when compared to content of other legumes such as winged bean (3-
5\%) and cowpea, hyacinth bean, soya bean, and common bean (4-5\%) as reported by Borget (1992). The commonly consumed legumes in Ethiopia such as Chickpeas (Cicer arietinum) and their fiber contents are: $4.80 \mathrm{~g} / 100 \mathrm{~g}$, Lentils (Lens culinaris) 2.30g/100g, Peas (Pisum sativum) $4.30 \mathrm{~g} / 100 \mathrm{~g}$, Vetch (Lathyrus sativus) $2.40 \mathrm{~g} / 100 \mathrm{~g}$, Broad beans (Vicia faba) 1.3g/100g (EHNRI, 1997). Those values were lower than the lima bean accessions under study.

The ash contents of accessions were ranged from $3.14 \%$ to $3.35 \%$. Accession "LB85CH2" had significantly higher $(3.35 \%)$ in ash content and was followed by "LB8510" (3.33\%) and "LB45CH" $(3.23 \%)$ in that order on dry weight basis and significantly $(\mathrm{p}<0.05)$ lower in Accession "LB45PL" (3.14\%). The mean ash composition $(3.26 \%)$ of the lima bean accessions in this study agreed with $3.3 \%$ for melon bean reported by Omafuvbe et al. (2004). The results were in agreement with the finding reported by Audu et al., (2011) for red kidney bean (3-5.8\%). The commonly consumed legumes in Ethiopia had ash contents: Lentils $2.20 \mathrm{~g} / 100 \mathrm{~g}$, Peas $3.0 \mathrm{~g} / 100 \mathrm{~g}$, Vetch $1.70 \mathrm{~g} / 100 \mathrm{~g}$, Lupine $2.50 \mathrm{~g} / 100 \mathrm{~g}$, and Broad beans 2.60g/100g (EHNRI, 1997). Those values were lower than the lima bean accessions under study.

The carbohydrate compositions of the accessions were varied from $53.17 \%$ to $54.40 \%$ in "LB8510" and "LB45CH", respectively. Accession "LB45CH" (54.40\%) had high utilizable carbohydrate. The mean of the accessions was agreed with the mean of $53.20 \%$ for some orphan legumes as described by Ogunlade et al. (2014). The mean was relatively comparable with the value $57.23 \%$ for lima bean accession reported by Yellavila et al. (2015). The mean utilizable carbohydrate of studied accessions was higher than the value reported by Borget (1992) for winged bean Pigeanpea and (35-45\%) and soya bean (40$45 \%)$ and lower than cow pea (60-65\%), hyacinth bean $(65-70 \%)$ and lima bean (70-75).

Table 1. Proximate compositions lima bean accessions

\begin{tabular}{llllllll}
\hline Accession & Moisture & $\begin{array}{l}\text { Crude } \\
\text { Protein }\end{array}$ & Crude Fat & $\begin{array}{l}\text { Crude } \\
\text { Fiber }\end{array}$ & Total ash & $\begin{array}{l}\text { Utilizable } \\
\text { Carbohydrate }\end{array}$ & $\begin{array}{l}\text { Gross energy } \\
(\mathrm{kcal} / 100 \mathrm{~g})\end{array}$ \\
\hline LB45CH & $9.52 \pm 0.00^{\mathrm{ab}}$ & $23.98 \pm 0.17^{\mathrm{d}}$ & $2.86 \pm 0.04^{\mathrm{a}}$ & $6.00 \pm 0.11^{\mathrm{a}}$ & $3.23 \pm 0.02^{\mathrm{ab}}$ & $54.01 \pm 0.09^{\mathrm{a}}$ & $337.7 \pm 1.46^{\mathrm{ab}}$ \\
LB45PL & $9.62 \pm 0.13^{\mathrm{ab}}$ & $24.33 \pm 0.18^{\mathrm{b}}$ & $2.94 \pm 0.04^{\mathrm{a}}$ & $5.59 \pm 0.16^{\mathrm{a}}$ & $3.14 \pm 0.04^{\mathrm{b}}$ & $54.38 \pm 0.23^{\mathrm{a}}$ & $341.3 \pm 0.60^{\mathrm{a}}$ \\
LB8510 & $9.84 \pm 0.01^{\mathrm{a}}$ & $24.76 \pm 0.09^{\mathrm{a}}$ & $2.87 \pm 0.03^{\mathrm{a}}$ & $6.03 \pm 0.21^{\mathrm{a}}$ & $3.33 \pm 0.04^{\mathrm{ab}}$ & $53.17 \pm 0.33^{\mathrm{a}}$ & $337.6 \pm 0.23^{\mathrm{ab}}$ \\
LB85CH2 & $9.32 \pm 0.02^{\mathrm{b}}$ & $24.06 \pm 0.09^{\mathrm{c}}$ & $2.78 \pm 0.11^{\mathrm{a}}$ & $6.09 \pm 0.37^{\mathrm{a}}$ & $3.35 \pm 0.01^{\mathrm{a}}$ & $54.40 \pm 0.56^{\mathrm{a}}$ & $338.86 \pm 0.91^{\mathrm{b}}$ \\
Mean & 9.58 & 24.28 & 2.8 & 5.92 & 3.26 & 53.99 & 338.87 \\
\hline
\end{tabular}

The mean of different superscript letters in the same column are significantly different $(p<0.05)$. Values are the means duplicate determinations \pm standard error. 
The gross energy contents of the studied accessions in this study were varied from $337.6 \mathrm{kcal} / 100 \mathrm{~g}$ in "LB8510" to $341.3 \mathrm{kcal} / 100 \mathrm{~g}$ in "LB45pL. The gross energy was significantly higher in "LB45PL" (341.3kcal $/ 100 \mathrm{~g})$ and was followed by "LB85CH2" (338.86kcal $/ 100 \mathrm{~g})$ and "LB45CH" $(337.7 \mathrm{kcal} / 100 \mathrm{~g})$ in that order, on dry weight basis. Accession "LB8510" 337.6kcal/100g had significantly $(\mathrm{p}<0.05)$ lower gross energy content than all accessions.

The mean gross energy contents of the accessions were $338.87 \mathrm{kca} / 100 \mathrm{~g}$. The mean of the accession was higher than the mean value $320.18 \mathrm{kcal} / 100 \mathrm{~g}$ for lima bean accession as reported by Yellavila et al. (2015). The commonly consumed legumes in Ethiopia had gross energy contents as Chickpeas $383 \mathrm{kcal} / 100 \mathrm{~g}$, Lentils $356.60 \mathrm{kcal} / 100 \mathrm{~g}$, Peas $352.20 \mathrm{kcal} / 100 \mathrm{~g}$, Vetch $360.50 \mathrm{~g} / 100 \mathrm{~g}$ and Broad beans $349.80 \mathrm{kcal} / 100 \mathrm{~g}$ as reported by EHNRI (1997). Those values were comparable with the lima bean accessions except Chickpeas $383 \mathrm{kcal} / 100 \mathrm{~g}$.

\section{Mineral compositions}

The calcium contents of lima bean accessions were shown in Table 2. The calcium concentrations were varied from 73.26 to $81.15 \mathrm{mg} / 100 \mathrm{~g}$. The calcium concentration was significantly high in "LB45CH" $(81.15 \mathrm{mg} / 100 \mathrm{~g})$ and was followed by "LB45PL" (76.45 mg/100g) and "LB85CH2" $(73.26 \mathrm{mg} / 100 \mathrm{~g})$ in that order, with low content in "LB8510" (68.67 mg/100g) accession on dry weight basis. The mean calcium contents of the accessions were $74.88 \mathrm{mg} / 100 \mathrm{~g}$. The result was higher than the mean calcium concentration (43.75 $\mathrm{mg} / 100 \mathrm{~g}$ ) for some underutilized legumes as described by Ogunlade et al. (2014). The mean calcium concentration was comparable to peas (Pisum sativum) $79.0 \mathrm{mg} / 100 \mathrm{~g}$ as reported by EHNRI(1997).

The zinc content of the studied accession in this study was varied $5.91 \mathrm{mg} / 100 \mathrm{~g}$ to $9.47 \mathrm{mg} / 100 \mathrm{~g}$ in" LB45CH" and "LB45PL" accessions, respectively. The zinc concentration of the accession "LB45PL" (9.47 mg/100g) was significantly higher and was followed by "LB8510" (8.66 mg/100g) and "LB85CH2" (7.31 $\mathrm{mg} / 100 \mathrm{~g}$ ) in that order while low in"LB45CH" $(5.91 \mathrm{mg} / 100 \mathrm{~g})$ accession. The mean zinc content of accessions under study was $7.24 \mathrm{mg} / 100 \mathrm{~g}$. The mean of the accessions was higher than the mean $2.49 \mathrm{mg} / 100 \mathrm{~g}$ for lima bean varieties reported by Seidu et al. (2018) and $2.64 \mathrm{mg} / 100 \mathrm{~g}$ for lima bean seed (Baddi et al., 2016).

The iron content of lima bean accessions varied from $91.62 \mathrm{mg} / 100 \mathrm{~g}$ to $128.48 \mathrm{mg} / 100 \mathrm{~g}$ in "LB8510" and "LB85CH2" accessions, respectively. The iron concentration of the accession "LB85CH2" was significantly high $(128.48 \mathrm{mg} / 100 \mathrm{~g})$ and was followed by "LB45PL" $(99.91 \mathrm{mg} / 100 \mathrm{~g})$ and $\mathrm{LB} 45 \mathrm{CH}(93.23 \mathrm{mg} / 100 \mathrm{~g})$. However, "LB8510" accession had the low iron contents $(91.62 \mathrm{mg} / 100 \mathrm{~g})$. The mean iron contents of the lima bean accessions were $103.31 \mathrm{mg} / 100 \mathrm{~g}$. The mean was higher than with the value 11.30 to $18.17 \mathrm{mg} / 100 \mathrm{~g}$ for some lima bean varieties reported by Seidu et al. (2018).

The magnesium content of the accessions under study was ranged from $19.88 \mathrm{mg} / 100 \mathrm{~g}$ to 37.27 $\mathrm{mg} / 100 \mathrm{~g}$ in "LB45CH" and "LB85CH2", respectively. Magnesium content "LB45CH2" accession was high $(37.27 \mathrm{mg} / 100 \mathrm{~g})$ and was trailed by "LB8510" (22.75 $\mathrm{mg} / 100 \mathrm{~g})$ and "LB45PL" (20.61 mg/100g) accessions. However, lima bean "LB45CH" accession was low (19.88 $\mathrm{mg} / 100 \mathrm{~g}$ ) on dry weight basis. The mean magnesium concentration of all lima bean accessions was $25.13 \mathrm{mg} / 100 \mathrm{~g}$. The mean was lower than $50.41 \mathrm{mg} / 100 \mathrm{~g}$ for lima bean varieties as reported by Seidu et al. (2018) and Baddi et al. (2016).

The phosphorous contents in present study were varied from $4.30 \mathrm{mg} / 100 \mathrm{~g}$ to $10.98 \mathrm{mg} / 100 \mathrm{~g}$ in "LB45PL" and "LB8510", respectively. Accession "LB8510" was significantly ( $<<0.05)$ higher $(10.98$ $\mathrm{mg} / 100 \mathrm{~g})$ and was followed by "LB45CH" (7.50 $\mathrm{mg} / 100 \mathrm{~g})$ and "LB85CH2" $(6.17 \mathrm{mg} / 100 \mathrm{~g})$ on dry weight basis.

Table 2. Mineral concentration of lima bean accessions ( $\mathrm{mg} / 100 \mathrm{~g})$

\begin{tabular}{llllllll}
\hline Accession & $\mathrm{Ca}$ & $\mathrm{Zn}$ & $\mathrm{Fe}$ & $\mathrm{Mg}$ & $\mathrm{P}$ & $\mathrm{Na}$ & $\mathrm{K}$ \\
\hline LB45CH & $81.15 \pm 1.0^{\mathrm{a}}$ & $5.91 \pm 0.1^{\mathrm{d}}$ & $93.23 \pm 1.1^{\mathrm{c}}$ & $19.88 \pm 0.0^{\mathrm{d}}$ & $7.50 \pm 0.5^{\mathrm{b}}$ & $51.66 \pm 3.73^{\mathrm{a}}$ & $35.58 \pm 1.6^{\mathrm{c}}$ \\
LB45PL & $76.45 \pm 2.88^{\mathrm{b}}$ & $9.47 \pm 0.1^{\mathrm{a}}$ & $99.91 \pm 1.7^{\mathrm{b}}$ & $20.61 \pm 0.2^{\mathrm{c}}$ & $4.30 \pm 0.5^{\mathrm{c}}$ & $52.88 \pm 2.06^{\mathrm{a}}$ & $32.39 \pm 0.9^{\mathrm{d}}$ \\
LB8510 & $68.67 \pm 0.7^{\mathrm{d}}$ & $8.66 \pm 0.1^{\mathrm{b}}$ & $91.62 \pm 1.0^{\mathrm{d}}$ & $22.75 \pm 0.3^{\mathrm{b}}$ & $10.98 \pm 0.3^{\mathrm{a}}$ & $60.66 \pm 3.85^{\mathrm{a}}$ & $37.03 \pm 1.7^{\mathrm{a}}$ \\
LB85CH2 & $73.26 \pm 4.6^{\mathrm{c}}$ & $7.31 \pm 0.0^{\mathrm{c}}$ & $128.47 \pm 0.2^{\mathrm{a}}$ & $37.27 \pm 0.9^{\mathrm{a}}$ & $6.17 \pm 0.1^{\mathrm{b}}$ & $58.65 \pm 0.48^{\mathrm{a}}$ & $36.79 \pm 1.1^{\mathrm{b}}$ \\
Mean & 74.88 & 7.84 & 103.31 & 25.13 & 7.24 & 55.96 & 35.45 \\
\hline
\end{tabular}


Mean with different superscript letters in the same column are significantly different. Values are the Means duplicate determinations \pm standard error

Accession"LB45PL" was lower $(4.30 \mathrm{mg} / 100 \mathrm{~g})$ than other accessions. The mean of phosphorous concentration of lima bean accessions were 7.24 $\mathrm{mg} / 100 \mathrm{~g}$. The mean of the accessions was lower than with the mean $14.28 \mathrm{mg} / 100 \mathrm{~g}$ for lima bean varieties and $13.25 \mathrm{mg} / 100 \mathrm{~g}$ for lima bean seed coats reported by Seidu et al. (2014).

The sodium content of lima bean accessions was ranged from $51.66 \mathrm{mg} / 100 \mathrm{~g}$ to $60.66 \mathrm{mg} / 100 \mathrm{~g}$ in "LB45CH" and "LLB8510", respectively. Accession "LB8510" was high $(60.66 \mathrm{mg} / 100 \mathrm{~g})$ in sodium content but did not significantly $(p<0.05)$ different from "LB85CH2" (58.65 mg/100g), "LB45PL" (52.88 $\mathrm{mg} / 100 \mathrm{~g})$ and "LB45CH" $(51.66 \mathrm{mg} / 100 \mathrm{~g})$ on dry weight basis. The sodium mean content of lima bean accession was 55.96 $\mathrm{mg} / 100 \mathrm{~g}$. The mean sodium content agreed with the mean $56.43 \mathrm{mg} / 100 \mathrm{~g}$ for lima bean varieties (seidu et al., 2018) and (Aremu et al., 2006). The mean was lower than the value reported by Seidu et al. (2014) $(82.20 \mathrm{mg} / 100 \mathrm{~g})$ for lima bean seed coat.

The potassium contents of studied accessions in this study were varied from $32.39 \mathrm{mg} / 100 \mathrm{~g}$ (LB45PL) to $37.03 \mathrm{mg} / 100 \mathrm{~g}$ (LB85CH2). The potassium content of the lima bean accession "LB8510" was significantly $(\mathrm{P}<0.05)$ high $(37.03$ $\mathrm{mg} / 100 \mathrm{~g})$ and trailed by "LB85CH2" (36.79 $\mathrm{mg} / 100 \mathrm{~g})$ and "LB45CH" (35.58 $\mathrm{mg} / 100 \mathrm{~g})$. Accession "LB45PL" was significantly $(p<0.05)$ lower $(32.39 \mathrm{mg} / 100 \mathrm{~g})$ than other accessions. The mean potassium concentration of lima bean accessions was $35.45 \mathrm{mg} / 100 \mathrm{~g}$. The mean of the accession was lower than $136.76 \mathrm{mg} / 100 \mathrm{~g}$ for raw lima bean flour (Oraka et al., 2017).

\section{Mineral ratios}

The sodium to potassium ratios present in the accessions was shown in Table.3.

Table 3. Mineral ratio of lima bean accessions

\begin{tabular}{|l|l|l|l|l|}
\hline Accession & Na:K & Ca:P & Ca:K & Fe:Zn \\
\hline LB45CH & 1.5 & 10.8 & 2.3 & 15.8 \\
\hline LB45PL & 1.6 & 17.8 & 2.4 & 10.6 \\
\hline LB8510 & 1.6 & 6.3 & 1.9 & 10.6 \\
\hline LB85CH2 & 1.6 & 11.9 & 2 & 17.6 \\
\hline Mean & 1.6 & 11.7 & 2.2 & 13.7 \\
\hline Standard & $<\mathbf{1}$ & $>\mathbf{0 . 5}$ & $<\mathbf{4}$ & $>\mathbf{2}$ \\
\hline
\end{tabular}

$\mathrm{Na} / \mathrm{K}$ ratios among the accessions ranged from 1.5 to 1.6 . The mean $\mathrm{Na} / \mathrm{K}$ ratio was 1.6 , which does not meet the standard, a ratio less than one considered as good source of the mineral balance.
Therefore, the $\mathrm{Na} / \mathrm{K}$ ratio in this study was greater than one, this shows that usual consumption of this accession may not prohibited high blood pressure in hypertensive patients and it needs further study. The ratio $\mathrm{Na} / \mathrm{K}$ is also stated as the life-death ratio in humans' physiology since the Sodium drive device and the electrical latent of cells is controlled by sodium and potassium levels.

Table 3 shows the Calcium to Potassium ratios of lima bean accession. The ratio of $\mathrm{Ca} / \mathrm{P}$ of the accessions was varied from 6.3-17.8. The mean $\mathrm{Ca} / \mathrm{P}$ ratio was 11.7 , which met the standard, a ratio greater than 0.5 considered as good source of the mineral balance. $\mathrm{Ca} / \mathrm{P}$ ratio greater than two also donates to the preoccupation of calcium in the small intestine (Adeyeye and Aye, 2005). Low Ca: $P$ ratio facilitates and control the acid-base balance of the blood and it is required in highest amounts by young child, pregnant and nursing mothers (Nieman al., 1992; Okaka et al., 2006).

The Sodium to potassium ratios present in the accessions was shown in Table 3. The calcium to potassium ratio of lima bean accessions was ranged from 1.9 to 2.4 . The mean calcium to potassium ratio of the accessions was 2.2 , which met the standard a ratio less than 4 considered as good source of the mineral balance. Thyroid ratio is known as calcium-potassium ratio because calcium and potassium play a vital role in regulating thyroid activity (Ojiezeh et al., 2016).

The Iron to zinc ratios of the lima bean accessions presented in Table 3. The $\mathrm{Fe} / \mathrm{Zn}$ ratio of the accessions varied from10.6 -17.6. The mean of Fe/ $\mathrm{Zn}$ ratio of the accessions was 13.7 , which met the standard, a ratio greater than 2 considered as good source of the mineral balance. Iron is critical to human life. It plays the central role in the hemoglobin molecule of our red blood cells, where it functions in transporting oxygen from the lungs to the body's tissues, and also transports carbon dioxide from the tissues to the lungs.

\section{Anti-nutritional factors of lima bean accession}

The condensed tannin contents of the accessions studied were presented in Table 4 . The condensed tannin contents of the accessions were varied from 29.44 to $116.46 \mathrm{mg} / 100 \mathrm{~g}$. The condensed tannin content of the accessions under study was significantly $(\mathrm{P}<0.05)$ high in "LB45CH" $(116.46$ $\mathrm{mg} / 100 \mathrm{~g}$ ) and was followed by "LB45PL" (91.19 $\mathrm{mg} / 100 \mathrm{~g})$ and "LB8510" $(47.23 \mathrm{mg} / 100 \mathrm{~g})$ in that order. Accession "LB85CH2" had lower (29.44 $\mathrm{mg} / 100 \mathrm{~g}$ than other accessions. 
The mean condensed tannin contents of studied accessions were $71.08 \mathrm{mg} / 100 \mathrm{~g}$. The mean of the accessions was higher than the value $10 \mathrm{mg} / 100 \mathrm{~g}$ for lima bean seeds reported by Baddi et al. (2015). The mean of the accessions in this study was within the permissible level and permissible limits of tannins $(20 \mathrm{mg} / \mathrm{g})$ for food crops as reported by Nididi et al. (2014). Tannin has ability to precipitate proteins, hinder digestive enzymes and absorption. It also inhibits both vitamin and mineral utilization in the meals (Tinko and Uyano, 2001).

Table 4. Anti-Nutritional factors of lima bean accessions (mg/100g)

\begin{tabular}{|l|l|l|l|}
\hline Accession & Tannin & Phytate & Oxalate \\
\hline LB45CH & $116.46 \pm$ & $101.81 \pm$ & $4.35 \pm$ \\
& $2.26^{\mathrm{a}}$ & $2.19^{\mathrm{c}}$ & $0.06^{\mathrm{c}}$ \\
\hline LB45PL & $91.19 \pm$ & $106.02 \pm$ & $4.48 \pm$ \\
& $2.25^{\mathrm{b}}$ & $0.00^{\mathrm{b}}$ & $0.06^{\mathrm{b}}$ \\
\hline LB8510 & $47.23 \pm$ & $111.41 \pm$ & $4.63 \pm$ \\
& $1.12^{\mathrm{c}}$ & $1.11^{\mathrm{a}}$ & $0.03^{\mathrm{a}}$ \\
\hline LB85CH2 & $29.44 \pm$ & $90.65 \pm$ & $4.38 \pm 0$ \\
& $1.13^{\mathrm{d}}$ & $1.54^{\mathrm{d}}$ & $.03^{\mathrm{d}}$ \\
\hline Mean & 71.08 & 102.47 & 4.46 \\
\hline
\end{tabular}

Mean values in the same column with different superscript letters are significantly different at ( $p$ <0.05). Values are the means of duplicate determinations \pm standard error

The phytate contents of lima bean accession in this study were ranged from $90.65 \mathrm{mg} / 100 \mathrm{~g}$ (LB85CH2) to $111.41 \mathrm{mg} / 100 \mathrm{~g}$ (LB8510). The phytate content of the "LB8510" accession was high (111.41 $\mathrm{mg} / 100 \mathrm{~g})$ and was trailed by "LB45PL" $106.02 \mathrm{mg} / 100 \mathrm{~g}$ ) and "LB45CH" $(101.81 \mathrm{mg} / 100 \mathrm{~g})$ accessions. However, accession "LB85CH2" had low $(90.65 \mathrm{mg} / 100 \mathrm{~g})$ phytate contents. The mean phytate contents of lima bean accessions studied were $102.47 \mathrm{mg} / 100 \mathrm{~g}$. The results were lower than with the value 336.3 $\mathrm{mg} / 100 \mathrm{~g}$ for lima bean seeds stated by Baddi et al., (2016). This finding revealed that phytate level of lima bean accessions were within the permissible level of phytate and permissible limits of phytate
( 250 to $500 \mathrm{mg} / 100 \mathrm{~g}$ ) for food crops as reported by Nididi et al. (2014). Phytate in food can bind essential nutrient digestibility and can cause mineral deficiencies (Bello et al., 2008).

The oxalate contents in this study were ranged from 4.35- $4.63 \mathrm{mg} / 100 \mathrm{~g}$. Accession "LB45CH" was lower than the oxalate contents of other accessions. Accession "LB45CH" was higher than the oxalate contents of other accessions. The mean oxalate contents studied accession was 4.46 $\mathrm{mg} / 100 \mathrm{~g}$. The mean of the accessions were lower than with the value $12.7 \mathrm{mg} / 100 \mathrm{~g}$ of raw lima bean reported by Baddi et al. (2015). The mean oxalate content was below the permissible limits of oxalates ( 3 to $5 \mathrm{mg} / \mathrm{kg}$ ) for food crops as reported by Nididi et al. (2014).

\section{Molar Ratio}

The molar ratio of phytate to calcium of all lima bean accession was ranged from 0.08 to 0.10 . In this study, the molar ratio of phytate to Calcium of all accession value was lower than the critical value $<0.24$. This showed that, the availability of calcium is good. Phytate: Calcium critical molar ratio is $<0.24$, which shows bioavailability of calcium is good (Woldegiorgis et al., 2015).

The phytate to zinc molar ratios of lima bean accessions were ranged from 1.11 to 1.66 , which is lower than the value reported as critical. The prediction of phytate to zinc molar ratio is taken as best indicator of zinc bioavailability status than the phytate levels alone. Phytate may reduce the bioavailability of dietary zinc by forming insoluble mineral chelates at a physiological $\mathrm{pH}$ (Oberleas, 1983). If the molar ratio of phytate to zinc <10, it considered as good zinc bioavailability. Whereas, if it is $>15$, considered as poor zinc bioavailability (Morris and Ellis, 1989). This indicates that, the lima bean accessions had good bioavailability of zinc.

The molar ratio of oxalate to calcium of lima bean accessions was 0.02 . In this study the ratio of oxalate to calcium was less than the critical value one. Oxalate can adversely affect the calcium if the ratio is greater than one (Frontela et al., 2009).

Table 5. Molar ratios of lima bean accessions

\begin{tabular}{|l|l|l|l|l|}
\hline $\begin{array}{l}\text { Accession } \\
\text { Name }\end{array}$ & $\begin{array}{l}\text { Phy:Ca } \\
\text { (Molar ratio) }\end{array}$ & $\begin{array}{l}\text { Phy:Zn } \\
\text { (Molar ratio) }\end{array}$ & $\begin{array}{l}\text { Phy:Fe } \\
\text { (Molar ratio) }\end{array}$ & $\begin{array}{l}\text { Ox: Ca } \\
\text { (Molar ratio) }\end{array}$ \\
\hline LB45CH & $0.08 \pm 0.00$ & $1.66 \pm 0.02$ & $0.09 \pm 0.00$ & $0.02 \pm 0.00$ \\
\hline LB45PL & $0.09 \pm 0.00$ & $1.11 \pm 0.01$ & $0.09 \pm 0.00$ & $0.02 \pm 0.00$ \\
\hline LB8510 & $0.10 \pm 0.00$ & $1.28 \pm 0.04$ & $0.10 \pm 0.00$ & $0.02 \pm 0.00$ \\
\hline LB85CH2 & $0.08 \pm 0.01$ & $1.24 \pm 0.04$ & $0.06 \pm 0.00$ & $0.02 \pm 0.00$ \\
\hline Standard & $<0.24$ & $<15$ & $<1$ & $<1$ \\
\hline
\end{tabular}




\section{Phenolic properties}

The total phenol contents in this study were ranged from $15.06 \mathrm{mg} / \mathrm{g}$ GAE to $31.59 \mathrm{mg} / \mathrm{g}$ GAE in "LB45PL" and "LB45CH", respectively (Table 6). Accession "LB45CH" was significantly $(p<0.05)$ higher $(31.59 \mathrm{mg} / \mathrm{g}$ GAE) and was followed by accession "LB85CH2" (29.29 mg/g GAE) and "LB8510" (26.38 mg/g GAE) on dry weight basis. Accession"LB45PL" had significantly $(p<0.05)$ lower $(15.06 \mathrm{mg} / \mathrm{g}$ GAE) than lima bean accessions under study. The mean total phenol contents of the studied accessions were $25.58 \mathrm{mg} / \mathrm{g}$ GAE. The mean of the accession in this study was comparable with the mean $27.16 \mathrm{mg} / \mathrm{g}$ GAE for legumes reported by Yan Zhao et al. (2014). The mean of accessions under study were higher than the mean $4.8 \mathrm{mg} / \mathrm{g}$ GAE for lima bean accessions described by Tania et al. (2015). The total phenol content of studied accessions was lower than 37.67 $\mathrm{mg} / \mathrm{g}$ GAE for lima bean seed coat as reported by Seidu et al. (2014).

The total flavonoid contents in this study were ranged from $9.35 \mathrm{mg} / \mathrm{g}$ QE (LB45PL) to 17.70 $\mathrm{mg} / \mathrm{gQE}(\mathrm{LB} 45 \mathrm{CH})$ and there was a significant difference $(\mathrm{P}<0.05)$ between the ranges. The accession "LB45CH" had the hightotal flavonoids content $(17.70 \mathrm{mg} / \mathrm{g} \mathrm{QE})$ and was followed by
"LB85CH2" (16.30 mg/g QE) and "LB8510" $(12.56 \mathrm{mg} / \mathrm{g}$ QE) in that order. However, accession "LB45PL" had the low $(9.35 \mathrm{mg} / \mathrm{g}$ QE) total flavonoids contents. The mean total flavonoid content in this study was $13.98 \mathrm{mg} / \mathrm{g}$ QE. Flavonoids are a ubiquitous group of polyphenolic substances, which are present in most plants. Good correlation between the total flavonoids content and antioxidant activity has been show indicating that the flavonoids contribute in free radical scavenging (Nyonje, 2015).

The DPPH radical scavenging activity of lima bean accessions "LB45CHO" was reached up to $13.81 \%$ at $20 \mathrm{mg} / \mathrm{ml}$ and55.88\% at $200 \mathrm{mg} / \mathrm{ml}$. The DPPH Scavenging activity of accession "LB45PL" 9.84\% at $20 \mathrm{mg} / \mathrm{ml}$ and $34.32 \%$ at $200 \mu \mathrm{g} / \mathrm{ml}$. At 20 $\mathrm{mg} / \mathrm{ml}$ the radical scavenging activity was $11.93 \%$ and $49.26 \%$ at $200 \mathrm{mg} / \mathrm{ml}$ with "LB85CH2" accession. Accession "LB8510" 12.50 to $20 \mathrm{mg} / \mathrm{ml}$ and 49.14 to $200 \mathrm{mg} / \mathrm{ml}$. In this study, the radical scavenging activity of lima bean accessions value $34.32 \%-55.88 \%$ at $200 \mathrm{mg} / \mathrm{ml}$ were lower than the value 2.62 to $94 \%$ for different lima bean accession reported by Tania et al. (2015). DPPH radical scavenging activity decreased in the order of Ascorbic acid > LB45CH > LB85CH2> LB8510 > LB45PL.

Table 6. Anti-oxidants of Lima bean accessions

\begin{tabular}{lll}
\hline Accessions & Total phenol mg/g GAE & Total flavonoids mg/g QE \\
\hline LB45CH & $31.59 \pm 1.70^{\mathrm{a}}$ & $17.70 \pm 0.02^{\mathrm{a}}$ \\
LB45PL & $15.06 \pm 0.54^{\mathrm{d}}$ & $9.35 \pm 0.14^{\mathrm{d}}$ \\
LB8510 & $26.38 \pm 1.51^{\mathrm{c}}$ & $12.56 \pm 0.07^{\mathrm{c}}$ \\
LB85CH2 & $29.29 \pm 0.61^{\mathrm{b}}$ & $16.30 \pm 1.37^{\mathrm{b}}$ \\
Mean & $25.58 \pm 2.44$ & $13.98 \pm 1.26$ \\
\hline
\end{tabular}

Different superscript letters mean values in the same column are considered as significantly different. Values are the means of duplicate determinations \pm standard error.

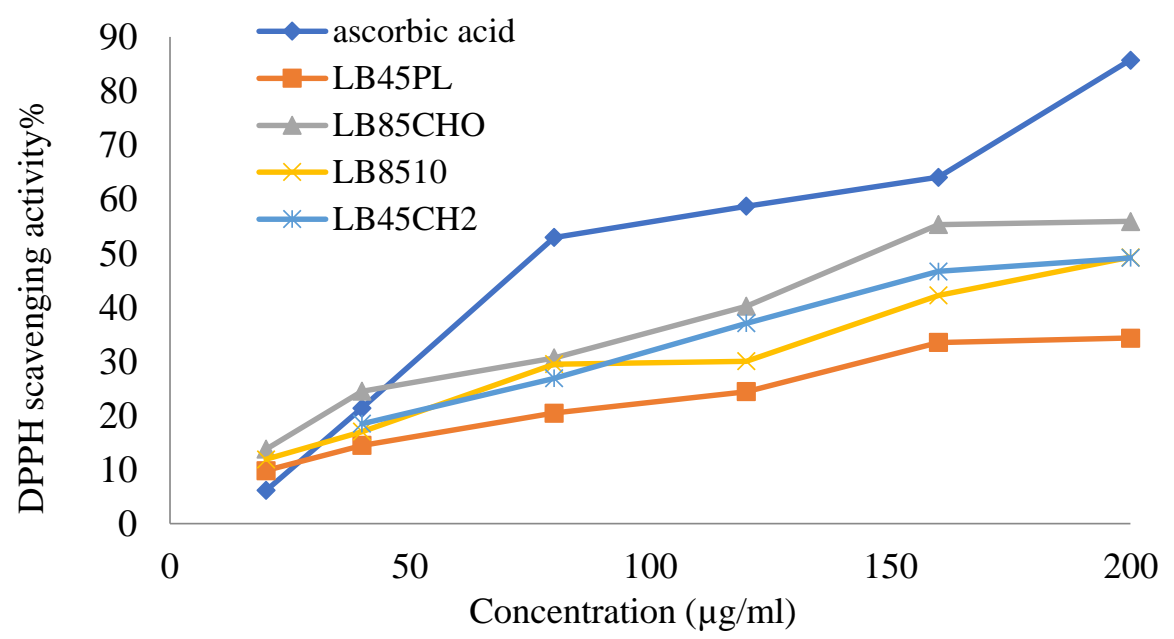

Figure 1. DPPH scavenging activity 


\section{CONCLUSION}

The result of the study showed that lima bean accessions were good source of essential nutrients when compared to the commonly consumed legumes in Ethiopia. Particularly, lima bean accessions "LB8510" rich in crude protein whereas accession "LB85CH2" rich in crude fiber, total ash and iron and therefore, can be implemented for breeding, new product development and alternative source nutrient rich that can mitigate malnutrition prevalent in Ethiopia. Therefore, increasing its consumption, cultivation and promotion should be encouraged.

\section{REFERENCES}

1. Abera, A. (2014). Nutritional and Antinutritional Constituents, and Minerals'Bioavailability of some wild and traditional vegetablesof the Gumuz ethnic community, Benishangul Gumuz Regional State, College of Natural Sciences Center for Food Science and Nutrition (Doctoral dissertation, Addis Ababa University).

2. Adebowale, Y. A., Adeyemi, A., \& Oshodi, A. A. (2005). Variability in the physicochemical, nutritional and antinutritional attributes of six Mucuna species. Food chemistry, 89(1), 37-48.

3. Adeyeye Emmanuel Ilesanmi and Adesina Adeolu Jonathan. (2018). Proximate and Mineral Compositions, Mineral Safety Index of Ten Organs of African Giant Pouch Rat. International Journal of Pharmacology, 9, 1-9.

4. Adeyeye, E. I., \& Aye, P. A. (2005). Chemical composition and the effect of salts on the food properties of Triticum durum whole meal flour. Pak. J. Nutr, 4(3), 187-196.

5. Amarteifio JO, Munthali DC, Karikare SK, Iqbal A, Khalil NA et al (2005). The composition of Lima bean Nutrition quality of important food legumes grown in Botswana.Nutr 57: 173-176.

6. AOAC (2000). Association of Official Analytical Chemists. In Association of Official Analytical Chemists (Vol. II). Washington, DC, USA: AOAC International: Washington, DC, USA.

7. AOAC (2016). Official methods of Analysis, Association of official Analytical Chemistry.

8. Apata, D.F. and Ologhobo, A.D (1994).Biochemical evaluation of some Nigerian legume seeds. Fd. Chem. 49: 333-338.

9. Aremu, M.O., Olaofe, O., Akintayo, E.T. 2006. Compositional evaluation of cowpea (Vigna unquiculata) and scarlet runner bean (Phaseolus coccineus) varieties grown in Nigeria. Journal of Food Agriculture and Environment 4(2): 39-43.

10. Arkroyed W.R. and Doughty J (1994). Legumes in Human Nutrition. Food and agricultural Nutrition Studies Publication. Lima Bean (Phaseolus lunatus). 1:349.

11. Aruah, B. C., M. I. Uguru, and B. C. Oyiga (2011). Nutritional evaluation of some Nigerian Pumpkins (Cucurbita spp.). Fruit, Vegetable Cereal Sci. Biotechnol. 5:64-71.

12. Arvouet-Grand, A., Vennat, B.,Pourrat, A. \& Legret, P. (1994). Standardisation d'un extrait de propolis et identification des principaux constituants. Journal de pharmacie de Belgique, 49, 462-468

13. Audu, S. S., Aremu, M. O. (2011). Nutritional composition of raw and processed pinto bean (Phaseolus vulgaris L.) grown in Plateau State, Nigeria. J. Food Agric. Environ. 9 (3\&4): 72-80.

14. Baddi Jayalaxmi, D. Vijayalakshmi, RavindraUsha and M.L. Revanna, R. Chandru and P.H.Ramanjini Gowda (2016). Effect of different processing methods on proximate, mineral and antinutrient content of lima bean (Phaseolus lunatus) seeds. Legume Research. P543 - 549.

15. Bello, M. O., O. S. Farade, S. R. A. Adewusi, and N. O.Olawore (2008).Studies of some lesser known Nigerian `fruits. Afr. J. Biotechnol. 7:3972-3979.

16. Borget, M. (1992). Food Legumes. Technical Centre for Agricultural and Rural Cooperation, Wageningen, the Netherlands.

17. Burns, R. E. (1971). Method for estimation of tannin in grain sorghum. Agronomy Journal, 63(3), 511512.

18. Bursal E and Gulcini I. (2011). Polyphenols contents and in vitro antioxidant activities of lyophilized aqueous extract of kiwifruit (Actinidiadeliciosa). Food Res Int.44: p1482 - 1489

19. Ethiopian Health and Nutrition Research Center EHNRI. (1997). Food composition table for use in Ethiopia. Part III. Addis Ababa.

20. Esenwah, C.N., Ikenebomeh, M. J (2008). Processing Effects on the Nutritional and Anti nutritional Contents of African Locust Bean (Perkiabiglobosa Benth) seed. Pakistan Journal of Nutrition, 7(2): 214217. 
21. Ezeagu, E. I and Ibegbu, M. D (2010).Biochemical composition and nutritional potential of ukpa: a variety of tropical Lima beans (Phaseolus lunatus) from Nigeria. Pol. J. Food Nutrition Science. 60(3): 231-235.

22. Fasoyiro, F. B., Ajibade, S. R., Omole, A. J, Adeniyan, O. N, Farinde, E. O. (2006). Proximate minerals and anti-nutritional factors of some underutilized legumes in south-western Nigeria. Nutr. Food Sci. 36: $18-23$.

23. Frontela C, Scarino ML, Ferruzza S, Ros G and Martínez .C (2009).Effect of dephytinization on bioavailability of iron, calcium and zinc from infant cereals assessed in the Caco-2 cell model. World $\mathrm{J}$ Gastroenterol 15: 1977-1984.

24. Genovese, Lajolo (2001). Proximate composition and functional properties of winged bean (Psophocarpus tetragonolobus). Nig J NutriSci 13: 36-38.

25. Guyot, J.P., Rochette, I., and Treche, S. (2007). Effect of fermentation by amylolytic lactic acid bacteria, in process combinations, on characteristics of rice/soybean slurries: A new method for preparing high energy density complementary foods for young children. Food Chemistry, 100; 623-63.

26. Iqbal A, Khalil IA, Ateeq N, Khan M.S. (2006). Nutritional quality of important food legumes. Food Chemistry 97: 331-335.

27. Latta M, Eskin M (1980). A simple and rapid colorimetric method for phytate determination. J. Agric Food Chem 28: 1313-1315.

28. Kathirvel, P. and Kumudha, P, 2011. A comparative study on the chemical composition of wild and cultivated germplasm of phaseolus lunatus L. Int J. App Bio and Pharm Tech., 2:296-305.

29. Michaels TE (2004). Pulses. Elsevier Ltd, University of Minnesota, St. Paul, MN, USA, Over view, pp 494-501.

30. Morris, E. R., \& Ellis, R. (1989). Usefulness of the dietary phytic acid/zinc molar ratio as an index of zinc bioavailability to rats and humans. Biological Trace Element Research, 19, 107-117.

31. Nieman, D.C., Butterworth, D.E. and Nieman, C.N. 1992. Nutrition.Wm. C. Brown Publishers, Dubuque, I. A. 540p.

32. Ndidi, U. S,Ndidi, C. U., Olagunju, A, Muhammad, A., Billy, F. G. and Okpe. O (2014). Proximate, anti-nutrients and mineral composition of raw and processed (boiled and roasted) Sphenostylisstenocarpa seeds from Southern Kaduna, Northwest Nigeria. ISRN Nutrition.19.

33. Nyonje, W. A. (2015). Nutrients, Anti-Nutrients and Phyotochemical Evaluation of Ten Vegetable Amaranth (Amaranthus spp.) Varieties at Two Stages of Growth. Msc Thesis.

34. Oberleas D (1983). Phytate content in cereals and legumes and methods of determination. Cereal Food World 28: 352-357.

35. Ogunlade, O. Olaofe and T. Fadare (2005). Chemical composition, amino acids and functional properties of some selected sea foods.J. Fd. Agriculture and Environment.Vol 3 (2): 130 - 133.

36. Ojiezeh, T. I., Adarabioyo, M. I and Olagbemide, P. T. (2016). Phyotochemical compositions of some extracts used in alternative medicine in Nigeria. Adv. Applied Sci. Res, 7, 1-6.

37. Ojinnaka MC, Ebinyasi CS, Ihemeje A, Okorie SU (2013). "Nutritional evaluation of Complementary food gruels formulated from blends of soybean flour and ginger modified cocoyam starch". Adv J Food Sci Tech. 5: 1325-1330.

38. Okaka, J. C., Akobundu, E. N. T and Okaka, A. N. T (2006). Food and Human Nutrition. An integrated Approach Ocjano Academic Publishers Enugu, Nigeria. Pp. 373-386.

39. Omoruyi FO, Dilworth L, Asemota HN (2007) Anti-nutritional factors, Zinc, Iron and Calcium in some Caribbean tuber crops and the effect of boiling or roasting. Nutrition and food science 37: 8-15

40. Omafuvbe, B.O., Falade, O.S. Osuntogun, B.A. and Adewusi, S.R.A. (2004). Chemical and biochemical changes in African locust bean (Perkia biglobosa) and melon (Citrullus vulgaris) seeds during fermentation to condiments. Pakistan Journal of Nutrition 3(3): 140-145.

41. Oraka, C. O. and Okoye, J. I. (2017). Effect of heat processing treatments on the chemical composition and functional properties of lima bean (Phaseolus lunatus) flour. American Journal of Food Science and Nutrition. Vol. 1, Issue 1, Pp. 14-24.

42. Pedrosa MM, Cuadrado C, Burbano C, Allaf K, Haddad J, Gelencsér E, Takács K, Guillamón E, Muzquiz M (2012). Effect of instant controlled pressure drop on the oligosaccharides, inositol phosphates, trypsin inhibitors and lectins contents of different legume. Food Chemistry; 131: 862-868

43. Sathya, A. and Siddhuraju, P, (2015). Effect of processing methods on compositional evaluation of underutilized legume, Parkiaroxburghii G. Don (yongchak) seeds. J. of Food Sci Technol. 52: 61576169. 
44. Seidu, K.T., Osundahunsi, O.F., Olaleye, M.T. and Oluwalana, I.B. (2014). Chemical composition, photochemical constituents and antioxidant potentials of lima bean seeds coat. Annals Food Science and Technology 15(2): 288- 298.

45. Seidu, K.T., Osundahunsi, O.F., Osamudiamen, P.M (2018). Nutrients assessments of some lima bean varieties grown in southwest Nigeria. International Food Research Journal 25(2): 848-853.

46. Singleton, V. L and Rossi, J.A. (1965).Colorimetry of total phenolic with phosphor molybdicphosphotungstic acid reagents. American Journal of Enology and Viticulture, 16(3), 144-158

47. Soetan and M.A. Fafunso (2010). Three Varieties of Lablab Beans (Lablab Purpureus) International Journal of Applied Agricultural Research ISSN 0973-2683 Volume 5 Number 3 pp. 291-300

48. Tania da SilveiraAgostini-Costa I, Ana FláviaPáduaTeodoro II, Rosa de Belem das Neves Alves I, Leandro RibeiroBraga III, Ieler Ferreira Ribeiro III, JoseanePadilhaSilva I, Luciane Gomes Quintana II, Marília Lobo BurleI (2015). Total phenolic, flavonoids, tannins and antioxidant activity of lima beans conserved in a Brazilian Genebank.Ciência Rural, Santa Maria, v.45, n.2, p.335-341.

49. Tinko $\mathrm{N}$ and K Uyano. (2001). Spectrophotometric determination of the tannin contents of various Turkish black tea, beer and wine samples. International Journal of Food Sciences and Nutrition. 52: 289294.

50. Tharanathan, R. N. and Mahadevamma (2003). Grain legumes, a boon to human nutrition. Trends in Food and Science Technology, 14, 507-551.

51. Ugwu, F. M., and N. A. Oranye (2006). Effects of some processing methods on the toxic components of African breadfruit (Treculiaafricana). Afr. J. Biotechnol. 5:2329-2333.

52. Ullah, R. J. A, I. Khader, N. M. Hussain, A. M. Talha and N. Khan (2012). Investigation of macro and micronutrients in selected medicinal plants". Afr. J.Pharm. Pharmacol. 69:1829-1832.

53. Wang, X., Chen, H., Ouyang, Y., Liu, J., Zhao, G., Bao, W., \& Yan, M. (2014). Dietary calcium intake and mortality risk from cardiovascular disease and all causes: a meta-analysis of prospective cohort studies. BMC medicine, 2(1), 158.

54. Woldegiorgis, A. Z., D. Abate G. D. Haki, and G. R. Ziegler (2015). Major, minor and toxic minerals and anti-nutrients composition in edible mushrooms collected from Ethiopia. Food Process. Technol. 6:134-142.

55. Yan Zhao, Shuang-kui Du, Hanxin Wang, MengCai (2014). In vitro antioxidant activity of extracts from common legumes. Food Chemistry 152 (2014) 462-466.

56. Yagoub, A. A., Mohammed, M. A., Baker, A.A (2008). Effect of soaking, sprouting and cooking on chemical composition, bioavailability of minerals and in vitro protein digestibility of Roselle (HibiscussabdariffaL.) seed.Pak. J. Nutri. 7: 50-56.

57. Yellavila, J.K. Agbenorhevi, J.Y. Asibuo, and G.O. Sampson (2015). Proximate Composition, Minerals Content and Functional Properties of Five Lima Bean Accessions." Journal of Food Security, vol. 3, no. 3: $69-74$. 